\title{
Abject Realism and the Depiction of Violence in Late Imperial Russian Crime Fiction:
}

\author{
The Case of N.P. Timofeev ${ }^{1}$
}

\section{Claire Whitehead}

\section{Introduction}

There has long been a tendency amongst commentators to analyze crime fiction in a rather sanitized fashion: the emphasis has fallen much more frequently upon the cerebral and the intellectual than upon the corporeal and material. Scholarship has preferred to focus on the play of the analytical, the performative (i.e. the detective disentangling clues), the metatextual and self-reflexive aspects of the genre rather than on a consideration of the violence that these works depict. ${ }^{2}$ This imbalance in criticism is somewhat ironic when we consider that a crime, often in the form of an act of (lethal) violence, is one of the defining characteristics of the genre. The response to Edgar Allan Poe's early, foundational crime stories is a striking case in point. The first, 'The Murders in the Rue Morgue' (1841), features graphic descriptions, recorded as excerpts from newspaper reports, of the murderous violence to which Madame L'Espanaye and her

\footnotetext{
${ }^{1}$ I am grateful to Deborah Martinsen and Bettina Bildhauer for their invaluable comments on drafts of this article. I would also like to thank the two anonymous peer reviewers for their very helpful suggestions.

${ }^{2}$ Examples of such work include Jacques Barzun, The Delights of Detection (New York, NJ: Criterion, 1961); Stephen Knight, Form and Ideology in Crime Fiction (London: Macmillan, 1980); Marty Roth, Foul and Fair Play: Reading Genre in Classic Detective Fiction (Athens, GA: University of Georgia Press, 1995); Heta Pyrhönen, Mayhem and Murder: Narrative and Moral Problems in the Detective Story (Toronto: University of Toronto Press, 1999).
} 
daughter have been subjected. The reader learns of a razor besmeared with blood, tresses of grey hair dabbled in blood, the still warm corpse of the daughter forced well up the chimney, head downwards, with scratches on her face and dark bruises and nail marks on her neck, and the body of her mother in the rear yard 'with her throat so entirely cut that, upon an attempt to raise her, the head fell off' ${ }^{3}$ The deposition of the doctor who inspects the women's bodies states:

The corpse of the mother was horribly mutilated. All the bones of the right leg and arm were more or less shattered. The left tibia much splintered, as well as all the ribs of the left side. Whole body dreadfully bruised and discoloured (...) The head of the deceased, when seen by witness, was entirely separated from the body, and was also greatly shattered. The throat had evidently been cut with some very sharp instrument - probably with a razor. ${ }^{4}$

Yet, despite the extended length and shocking nature of these descriptions of the effects of violence, what commentators have preferred to focus on in Poe's work - in line with the intellectually contemplative nature of the story's opening passages - is the archetype provided by Auguste Dupin of the dispassionate, rational investigator who aims to solve the mystery of the crime through the application of logical analysis. ${ }^{5}$

${ }^{3}$ Edgar Allan Poe, 'The Murders in the Rue Morgue', The Fall of the House of Usher and Other Writings (London: Penguin, 1986), p.198.

4 ibid., p.203.

5 The first three pages of 'The Murders in the Rue Morgue' are devoted to a discussion by the narrator of 'the mental features discoursed of as the analytical' (p.189). Chiming with this preoccupation, John T. Irwin's 1994 study, for instance, uses the work of Poe and 
Such an approach is mirrored in the critical reception of early Russian crime fiction, an aspect of the country's literary history that has recently begun to receive the attention it deserves. Louise McReynolds' Murder Most Russian: True Crime and Punishment in Late Imperial Russia (2013) reveals how criminal violence was recorded in court stenographic reports and journalism but, as befits an historical study of true crime reports, says little about how this feature translates into literary-fictional portrayal. In my own recently published study, The Poetics of Early Russian Crime Fiction 1860-1917, there is no sustained discussion of the aesthetics of violence in the works that form my corpus. ${ }^{6}$ Rather, the analysis focuses on the various narrative features (authority, voice, temporality, intertextuality and metatextuality) that characterize the genre during its early years of development. Similarly, Anthony Olcott's Russian Pulp: The Detektiv and the Russian Way of Crime (2001), which considers examples from the post-Soviet period,

Jorge Luis Borges to examine the figure of the analytic detective whilst Patricia Merivale and Susan Sweeney focus on this character's role in the creation of postmodern detective fiction. See John T. Irwin, The Mystery to a Solution: Poe, Borges and the analytic detective story (Baltimore, MD: John Hopkins University Press, 1994); Patricia Merivale \& Susan Elizabeth Sweeney (eds.), Detecting Texts: The Metaphysical Detective Story from Poe to Postmodernism (Philadelphia, PA: University of Pennsylvania Press, 1999). One might also mention Peter Thoms' chapter, 'Poe's Dupin and the power of detection' in Kevin J. Hayes (ed.), The Cambridge Companion to Edgar Allan Poe (Cambridge, Cambridge University Press, 2006), pp.133-47.

${ }^{6}$ See Claire Whitehead, The Poetics of Early Russian Crime Fiction, 1860-1917: Deciphering Tales of Detection (Oxford: Legenda, 2018). 
recognizes 'all the gore' in the genre but offers no analysis of this phenomenon. ${ }^{7}$ To some extent, the lack of engagement with the issue of violence in such scholarship can be justified by the fact that, in many works of early Russian crime fiction, the act of violence and its immediate aftermath is elided and not dwelt upon in any detail. For instance, one of the first works of home-grown crime fiction to be published in Russia, Nikolai Sokolovskii's story 'Nabolevshie' ['The Long-Suffering'] from 1863, centres around the case of a young woman, Daria Iakovleva, who has survived being stabbed in the chest by her lover. The judicial investigator assigned to the case is informed of the incident by what he refers to as 'lakonicheskoe uvedomlenie politsii' ['a laconic police report'] that provides summary details of Daria's wound and of the dried-up bloodstains on a knife. When the investigator visits the victim in hospital immediately upon receipt of this report, he provides a brief description of the wounds she has suffered: one in the chest and two on her arms, as well as defensive wounds on her fingers. However, no further details of the resulting physical trauma are provided. Many more such examples could be provided of early Russian crime fiction's disinclination to portray violence, because this was the overwhelming generic convention at the time. ${ }^{8}$

\footnotetext{
${ }^{7}$ Anthony Olcott, Russian Pulp: The Detektiv and the Russian Way of Crime (New York \& Oxford: Rowman \& Littlefield, 2001), p.20.

${ }^{8}$ For instance, in Aleksandr Shkliarevskii's 'Sekretnoe sledstvie' ['A Secret Investigation'] from 1881, the picture is even more sanitized. Although the narrator-detective's investigation is prompted by the poisoning of a young woman, the text provides no detailed account of this crime. The description of how the victim arrives back at her residence in a carriage is devoted as much to her beauty and her dress as it is to the fact that she is close to death. Indeed, the servant who greets the carriage initially thinks she
} 
However, it would be misleading to suggest that all works of Russian crime fiction in the late Imperial period conform to this model. In fact, there are a number of works that present the reader with extended and detailed depictions of violence; and it is important that these not be ignored. The literary practice on display in these accounts of violence and its aftermath can most productively be considered as an extension of the aesthetic of nineteenth-century critical realism. Works of nineteenth-century Russian crime fiction establish a conventional degree of verisimilitude in various ways: they frequently set their action in a named and recognizable location; they populate the fictional world with authentic-seeming characters; they introduce the reader to the work of the newlyinstituted historical figure of the judicial investigator; and they do not shy away from the less salubrious aspects of human behaviour and social organization. ${ }^{9}$ However, the works to be discussed in this article move well beyond this base line of realism to offer something more extreme and radical. At times, their descriptions of violence exceed the boundaries of more conventional realism by depicting a disfiguring and defamiliarization

is asleep on the floor before realizing that her face is convulsing and her eyes are glassy. These brief details represent the extent of the description of her death.

${ }^{9}$ It is also worth stating that several of the earliest works of Russian crime fiction include a foreword in which the author makes explicit claims regarding the authenticity and realism of his account. This is the case for Timofeev's Zapiski sledovatelia [Notes of an Investigator] (St Petersburg: Plotnikov, 1872), in which the reader is informed that the account to follow comprises 'events taken from the real world' (p.5). 
of the body that qualifies as grotesque. ${ }^{10}$ On the whole, however, it is more accurate to characterize these depictions as instances of 'abject realism', to borrow a term from Edith Clowes. Clowes elaborates this notion in a discussion of three non-crime stories by Leonid Andreev that, she claims, employ 'an entirely expressionist style' and that 'radicalized the defining features of classical nineteenth-century realism to peel away social taboos and expose the horror of human existence'. ${ }^{11}$ The works of early Russian crime fiction discussed here, which feature explicit and extended depictions of violence and violated bodies, but which pre-date Andreev by some thirty years or so, showcase a similar desire to experiment with, and push beyond, the limits of more traditional realism. Indeed, a number of the claims that Clowes makes about the role of abject realism in Andreev's stories are applicable to the earlier Russian crime stories to be analyzed

10 The use of the term 'conventional realism' here is not intended to imply that there is or was only one type of this literary mode: realism exists in many different forms, as practiced by various authors in different national traditions during different historical periods. However, this article does argue that the examples to be discussed here move beyond a depiction of simply the 'ordinary', 'the non-beautified world' or the 'ugly' that Peter Brooks identifies as characteristic tendencies of the mode in Realist Vision (New Haven \& London: Yale University Press, 2005), pp.7-8. For a fuller discussion of specifically grotesque realism in the late nineteenth century in Russia, see Ani Kokobobo, Grotesque Realism: The Great Reforms and the Gentry Decline (Columbus, OH: Ohio State University Press, 2018).

11 Edith W. Clowes, 'The mute body: Leonid Andreev's abject realism', in Katherine Bowers \& Ani Kokobobo (eds.), Russian Writers and the Fin-de-Siècle: The Twilight of Realism (Cambridge: Cambridge University Press, 2015), pp.233-48 (p.235). 
here. ${ }^{12}$ As a consequence, a consideration of crime fiction's exploitation of abject realism can serve to extend not only our understanding of the variety that exists within crime fiction but also of the ways in which this particular form of realism functions and of the effects that it can create.

It appears broadly appropriate - that is, outside the issue of the depiction of violence specifically - to consider crime fiction through the prism of abjection. In Powers of Horror, Julia Kristeva explains that what causes abjection is 'what disturbs identity, system, order. What does not respect borders, positions, rules'.13 Predicated as it is on a transgression of the boundary between legal and illegal, crime fiction depicts disturbances of various kinds to order, even if much criticism views it as an essentially conservative form in which such disruptions are ultimately resolved. Kristeva herself claims that 'any crime, because it draws attention to the fragility of the law, is abject, but premeditated crime, cunning murder, hypocritical revenge are even more so because

${ }^{12}$ As the discussion to follow will illustrate, the work of Andreev and N.P. Timofeev shares a 'focus on the theme of the abused body in a variety of forms' (Clowes, p.234), demonstrate a preoccupation with the 'mute body' (Clowes, p.235) and, in their practice of abject realism, promote senses other than the visual in observation (e.g. touch and smell) as being equally important to vision. The work of Timofeev to be discussed here does not, however, give expression to unconscious fears in the same way as do the stories of Andreev, nor does it focus in any significant manner on the figure of the abused female body.

13 Julia Kristeva, Powers of Horror: An Essay on Abjection (New York, NY: Columbia University Press, 1982), p.4. 
they heighten the display of such fragility'. Of more particular relevance to the subject of this article, she outlines how 'the corpse, seen without God and outside of science, is the utmost of abjection. It is death infecting life'. ${ }^{14}$ Kristeva argues that the abject encompasses the physical and material and that it is concerned with psychological and spiritual manifestations as well as liminal instantiations that hover between the two. With regards to the former, at various points of her study, Kristeva identifies blood, pus, dirt, decay, decomposition, as well as other substances, as being related to the abject. The abject realism of the works discussed below entails a refusal to look away from such elements, and instead a determination to acknowledge, in considerable detail and with reference to various of the senses, not only the visual, the fact of their existence. A more sustained focus on such subject matter seems especially appropriate to crime fiction, as David Trotter explains:

it is to dirt, therefore, to refuse, to matter out of place, that the detective looks first: the dirt which is the corpse, and the dirt which surrounds the corpse. Footprints, fingerprints, hairs, threads, bloodstains. (...) In detective fiction, the stuff to be deciphered is also the stuff of moral and material horror. ${ }^{15}$

Trotter's reference here to 'moral horror' obliquely echoes Kristeva's contention that the experience of abjection involves a strong psychological, emotional, or spiritual aspect. In the texts to be analyzed here the realistic portrayal of violence and its consequences confronts the reader with scenes that blur the lines between subject and object, self and

\footnotetext{
14 ibid.

15 David Trotter, 'Theory and Detective Fiction', The Critical Quarterly, 33:2 (1991), pp.6677 (pp.70-1).
} 
other, consciousness and unconsciousness, human and non-human, in ways that both speak of and provoke a sense of the psychological abject. The use of abject realism brings the reader to that place 'where meaning collapses'16 and where seemingly reassuring structures - of family, society and individual identity - are violently challenged.

Although not the generic norm, there are a number of narratives in late Imperial-era Russian crime fiction in which the scenes of violence and its aftermath are depicted with abject realism. A.A. Shkliarevskii's story 'Utro posle bala: rasskaz prisiazhnogo poverennogo' ['The Morning After the Ball: A Barrister's Tale'], published in 1878, depicts in harrowing detail the scene in a private bathhouse where a woman has been stabbed in the neck and has had her face peeled off. Both the degree of verisimilitude it employs and the destruction of individual identity it details serve to categorize this description as abjectly realist. Albeit in a less violently shocking manner, A.E. Zarin's 1915 novella, $V$ poiskakh ubiitsy [In Search of a Murderer], also employs an abject form of realism in its description of the discovery of a dismembered body, part of which is found in a rubbish dump, part of which is dragged in to a kitchen by a dog, and the head of which is discovered in a parcel that has been sent via a Petersburg railway station. However, it is unquestionably the work of N.P. Timofeev that offers the most striking examples of this practice in early Russian crime fiction. Nikolai Timofeev worked as a criminal investigator in the mid-nineteenth century before becoming a well-known barrister later in his career, and he drew on this experience to inform much of his fictional and nonfictional writing. Throughout the 1870 s and 1880s, he regularly published works of crime

16 Kristeva, Powers of Horror, p.2. 
fiction and memoir, which proved to be extremely popular with the contemporary readership.

This article concentrates on two of Timofeev's works in particular: 'Prestuplenie sueveriia' ['A Crime of Superstition'] from 1872; and 'Na sovesti: psikhologicheskii ocherk' ['On One's Conscience: A Psychological Sketch'] published in 1879. 'A Crime of Superstition' appeared in the collection, Zapiski sledovatelia [Notes of an Investigator], which includes seven stories featuring an unnamed narrator-detective, all of which straddle the autobiography / fiction divide. As the narrator - a judicial investigator recounts the gruesome details of his investigation into a case of the disinterment of six bodies from a cemetery, one of which has been horribly mutilated, readers witness Timofeev's use of abject realism at its most pronounced. 'On One's Conscience', similarly narrated by a judicial investigator, involves the case of man who, having attempted to murder his wife, performs repeated acts of realistically described self-harm before eventually committing suicide. In both of these works, detective and reader are confronted with images, situations and behaviour that instil a strong sense of both the material and the psychological abject.

The aim of this article is not only to establish what abject realism looks like in works of crime fiction, but also to offer an interpretation of its function and effects. It examines the impact that this extreme aesthetic makes in narrative terms, especially to the characterization of the detective protagonist. During the genre's formative years in the 1860s and 1870s, Russian crime fiction of all hues promoted the figure of the judicial investigator as a positive hero. Works that employ passages of abject realism, however, make that case both more stridently and more ambiguously. This extreme realism also 
plays a significant role in constructing hierarchies of social and diegetic authority in early Russian crime fiction. However, the depiction of violence naturally suggests a broader perspective, very much in line with McReynolds' claim that a study of true crime in the late Imperial period has something to teach us about the 'cultural values, political norms, and social expectations' operating in Russia at the time. ${ }^{17}$ The discussion to follow therefore considers how Timofeev's stories employ the abject to critique particular cultural beliefs and social institutions or patterns of social organization - including social class, religion, superstition, education - and their deleterious consequences. As Ani Kokobobo has argued recently with regards to the use of 'grotesque realism' in different works from the same period, an exaggerated form of literary verisimilitude is a more effective tool for social criticism than conventional realism, which tends to reinforce the status quo. ${ }^{18}$ She defines 'grotesque realism', as manifested in the gentry novel, as a form that emphasizes defamiliarization, dehumanization, despiritualization, and hybridization. These elements of Kokobobo's definition demonstrate significant areas of overlap with Clowes' discussion of 'abject realism' and are equally applicable to Timofeev's work. However, the sense of inversion, of profound instability and, especially, of the metaphorical in Kokobobo's 'grotesque realism' distances it from the abject and from Timofeev's practice. ${ }^{19}$ Both of the Timofeev narratives discussed here depict life in the post-reform period of the 1860-70s ('A Crime of Superstition' takes place in 1865 whilst the action of 'On One's Conscience' is undated but certainly post-1864), when the figure of the judicial investigator embodied the reorganized judicial system. I will

\footnotetext{
${ }^{17}$ McReynolds, Murder Most Russian, p.14.

${ }^{18}$ Kokobobo, Grotesque Realism, p.11.

19 Kokobobo, Grotesque Realism, pp.13-15.
} 
therefore consider how the texts interrogate, by means of their use of the abject, the consequences of judicial reform upon the realities of Russian life in this period. However, in a less historically or geographically determined fashion, I will also show how the depiction of violence in these works points up the antagonism between various of the binaries that are fundamental to all human existence.

\section{Timofeev’s ‘A Crime of Superstition’ (1872)}

Among the group of writers who initiated the genre of crime fiction in Russia, Nikolai Timofeev makes the most sustained use of the abject in his descriptions of violence. Indeed, in these very early years of the genre, Timofeev represents something of a case apart. Neither of his contemporaries, Nikolai Sokolovskii or Petr Stepanov, include any extended accounts of violence in their stories, even though their work and Timofeev's share many other features. Fedor Dostoevskii's novel Crime and Punishment, first published in 1866, also falls outside of the scope of the present discussion. As is well known, the novel includes various scenes that describe the perpetration of violence most notably Raskolnikov's murder of the pawnbroker, Aliona Ivanovna, and her sister, Lizaveta. However, two factors prevent these descriptions from creating a sense of the abject. First, they deal with the 'present' moment of the commission of criminal violence, rather than with its aftermath: at least at their outset, these descriptions focus on bodies that are still alive rather than on corpses, a fact that distances them from abjection. Nevertheless, as ‘On One’s Conscience’ illustrates, live bodies are still capable of evoking a sense of the abject, and so a second element in Dostoevskii's novel must also be considered. The murders are visualized from the perspective of the perpetrator as he commits the crimes, rather than from that of an external observer, who occupies a position more removed both psychologically and temporally from the criminal action. 
Dostoevskii clearly deploys realism in these passages of description (I have written elsewhere about the effect that narrative pace has upon the sense of verisimilitude they create), but it does not evoke the sense of disgust or revulsion characteristic of the examples to be discussed below. ${ }^{20}$

The opening of Timofeev's 'A Crime of Superstition' is generically conventional, and its early pursuit of verisimilitude does nothing to suggest its subsequent move to radical realism. The narrator provides fairly precise geographical and temporal coordinates for the action: the village of Gerdovaia in the district of $0^{* * *}$ during the summer of 1865 . Initial details of the case are provided indirectly in the report that the police bailiff makes to the judicial investigator: six coffins have been unearthed and opened. The corpses have been removed and are now strewn around the graveyard. While perhaps shocking in its bare facts (the narrator refers to it as an act of 'sacrilege'), this first description does not qualify as abject. Moreover, it is quite distinct in both nature and impact from those provided once the narrator has himself travelled to Gerdovaia to commence his investigation. The earliest indications that Timofeev's story will not shy away from depicting the consequences of criminal violence come in a series of references to the smell that confronts the narrator-detective as he arrives in the village. While smell is a

20 See my The Poetics of Russian Crime Fiction, pp.154-55. There is a similar lack of abjection in the descriptions of the violent episodes that occur in Raskolnikov's various dreams. His dream of Mikolka beating the mare to death is shocking in its violence but does not provoke the same sense of aversion in the reader; neither does the dream of Ilia Petrovich beating Raskolnikov's landlady nor the protagonist's dream of returning to Aliona Ivanovna's rooms and attempting to murder the pawnbroker again. 
comparatively undertheorized aspect of abjection, it figures as an important adjunct to the more usual visually informed descriptions. Indeed, Timofeev chooses to amplify the impact of these olfactory descriptions. By activating readers' awareness of the stench, the narrator also delays the more direct, visual revelation of the crime scene: 'Priblizhaias' $\mathrm{k}$ derevne so storony kladbishcha, ia eshche izdali pochuvstvoval nesterpimyi zapakh ot razlagavshikhsia trupov' ['Approaching the village from the side where the cemetery was located, I could already, from a long way off, detect the unbearable stench coming from the decomposed corpses'].21 The narrator underscores the strength and effect of this smell in order to explain, at least in part, the profound state of shock and anxiety in which he finds the Gerdovaia villagers as they stand huddled in a crowd, occasionally glancing at the cemetery. The abject motif of decomposition dominates here. The narrator stresses it again when he reports how the villagers look fearfully in the direction of the cemetery where 'to tam to siam vidnelis' ochertaniia vykinutykh iz mogil grobov i pokoinikov, lezhavshikh v raznykh pozakh i obezobrazhennykh sil'noiu stepen'iu gnilosti' ['here and there glimpses of the disinterred coffins and corpses were visible, lying in various poses and disfigured by an extreme degree of decomposition'] (291). While many other works of crime fiction would likely not have gone beyond these initial descriptions, 'A Crime of Superstition' goes even further when the narrator emphasizes the decomposition of the bodies and their effect: 'vozdukh v derevne ot sil'no razlagavshikhsia trupov, tselyi den' pripekaemykh paliatsimi luchami solntsa, byl nevynosim' ['the air in the village, from the badly decomposed corpses heated up all day long by the burning rays of the sun, was

21 'A Crime of Superstition', in Notes of an Investigator (St Petersburg, Plotnikov, 1872), p.291. Hereafter, all references to this story are included in brackets in the main body of the article. 
unbearable'] (292). The narrator first establishes the fact of the stench hanging over the village; his repeated mention of it here reveals his extreme approach to realist description.

The effect created by the first direct visual account of the crime scene is heightened in part because it is delayed. The investigator claims that it is too close to dusk on the day he arrives for him to inspect the graveyard. Instead, he offers a four-page account of the evening that he spends with the village elder, who reveals his superstitious beliefs, the relevance of which will be discussed below. The following morning, when the investigator sets out to the cemetery, he again refers to the 'unbearable' smell which he attributes to the 'gnienie neskol'kikh trupov' ['the putridity of several corpses'] (297). This smell is so strong that, in spite of the fact that they are all smoking pipes in an effort to dissipate it, the local men who accompany him as witnesses attempt to leave on several occasions. Before providing his first direct, visually informed account of the graveyard, the narrator builds further suspense by informing the reader that what he saw that day 'bylo po istine uzhasnoe' ['was in truth horrifying'] and inspired such feelings of 'neponiatnogo strakha i kakogo-to otvrashcheniia' ['incomprehensible fear and some sort of revulsion'] (297) that, at the time of writing, many years later, they have still not entirely left him. By admitting his profound affective response to a scene that has yet to be described in detail, the narrator further increases the reader's sense of anticipation. However, he also outlines a professional justification for the detailed nature of the description to follow that explicitly links the practice of literary realism with the investigator's obligation to find the truth. He explains:

Опишу последовательно и во всей подробности все, что я нашел на кладбище, так как тщательная детальность и рельефность во всех подобных 
следственных приемах, составляет в практике следователя тот режим, который необходим для раскрытия истины. (297)

I will describe everything that I found in the cemetery carefully and in full detail because exercizing a meticulous level of detail and relief in all such investigations constitutes an approach to the job of the investigator that is essential in order to discover the truth.

In the context of nineteenth-century writing, such an explicit association between the detective's moral and epistemological duty to establish the truth on the one hand, and the pursuit of literary realism on the other, is an unmistakably value-laden move. Not only does it lend a moral weight to the relatively new genre of crime fiction in Russia, it also offers a pre-emptive justification for the use of abject realism in the specific context of Timofeev's story. Timofeev's narrator-detective implies that to shy away from such a 'meticulous' level of realistic detail would be to conduct a partial and thereby flawed search for the truth.

In the description that follows, which is striking both for its length and its unwavering detail, Timofeev's practice of abject realism in 'A Crime of Superstition' is at its most developed. The cemetery as crime scene has obvious potential as an abject location, not only in terms of its (historically accurate) geographical position on the edge of the village, but also as a heterotopia housing a liminal community: the dead who are nevertheless preserved as a part of the living society. ${ }^{22}$ The narrator's observations are recorded in a

${ }^{22}$ In Foucault's lecture to architects, the cemetery is the most prevalent example of a heterotopia. For Foucault, the cemetery not only represents a profound spatio-temporal 
seemingly methodical manner, proceeding from one body to another as if imitating the movement of his gaze, a formal construction that strikingly contrasts to the profound disruption represented by the state of the disinterred bodies. The narrator's attention first falls upon 'sovershenno sgnivshii uzhe trup kakogo-to cheloveka, po-vidimomu starika, o chem ia mog sudit' tol'ko po sedym volosam na sovershenno peregnivshikh pokrovakh golovy' ['an already completely putrefied corpse of some person or other, apparently an old man, a fact I could only judge by the grey hairs on his completely rotted scalp'] (297). The repeated references to decomposition (variants of the verb 'gnit" in Russian) in this sentence, which echo those found in the earlier descriptions of the smell hanging over the village, evoke a sense of the abject here. Moreover, by means of defamiliarizing phrases, the narrator emphasizes the dehumanizing effect of burial and disinterment on this and the other corpses. The first corpse belongs to 'kakogo-to cheloveka' ['some person or other'] whose 'ruki [...] kak-to stranno uperlis' pod zhivot' ['arms were somehow strangely crossed beneath his stomach'], whilst his legs were in a position that made it 'seem as though' he was attempting to stand up (297). Indeed, the narrator's account of the bodies' condition abounds in indefinite modifiers such as 'kakoito' and 'kak-to'. The old man's right leg is also folded under his body with the foot 'kak-to vypiatilas' stupnei v storonu' ['somehow sticking out to the side'], while another body belongs to 'kakaia-to starukha' ['some old woman'] and there is also 'kakoi-to molodoi paren" ['some young man or other'] (298). These indefinite pronouns and adverbs not only give effective voice to the narrator's shock and the difficulty he has in finding the

disruption, it is a place that constitutes an 'absolute break with traditional time'. See Michel Foucault, 'Different Spaces', in J.D. Faubion (ed.) Power: Essential Works of Foucault, 1954-1984 (London: Penguin, 1998), pp.175-85 (p.182). 
appropriate terms for his description, they also underscore the manner in which decomposition has rendered the bodies somehow ambiguous, not entirely human. Consequently, these modifiers eloquently express the 'threat to identity' that these decaying corpses represent and which Kristeva associates with the abject. ${ }^{23}$

The narrator's attention moves next to the corpses of a young girl and a second old man, both lying next to the first body. Here, the narrator's use of contrast and unexpected phrasing reinforces the effect of his unflinching approach to describing the scene. For instance, although these are dead bodies, the investigator repeatedly refers to their 'freshness', such as when he notes that, 'oba oni byli dovol'no svezhi' ['they were both fairly fresh']. The account also includes a rather unconventional use of diminutive forms: he refers to the old man as a 'muzhichek' ('peasant fellow'); and he notes that for the young girl 'sokhranilis' eshche vpolne cherty ee milogo, prekrasnogo lichika, okaimlennogo belokuryvi volosami' ['the features of her sweet, beautiful little face were almost entirely preserved, and framed by curly blond hair'] (298, my italics). While these diminutives reveal, on the one hand, the empathy that the narrator-investigator feels for the dead figures, their use in reference to corpses is disconcerting. Moreover, having highlighted the prettiness of the young girl's face, the narrator notes how he shudders at the thought of its imminent transformation: '[ono] obratitsia v seruiu kashitseobraznuiu voniuchuiu massu, kotoraia vnushat' odno tol'ko otvrashenie' ['[it] will turn into a grey

${ }^{23}$ Kristeva, Powers of Horror, p.101. Such indefinite modifiers are notably absent from the doctor's report of the two women's bodies in Poe's 'Murders in the Rue Morgue' quoted above. This more confident attitude in Poe's description, likely intended to reflect the doctor's scientific approach, is one reason why this description is not abject. 
gruel-like fetid mass, that will only inspire revulsion'] (298). The various contrasts at play here between 'features' and 'mass', 'blond' and 'grey', 'beautiful' and 'fetid', as well as the reference to a textural materiality ('gruel-like') are effective in provoking a profound sense of aversion. Crucially, this is the one occasion where Timofeev's narrator is not describing an observable reality, but instead imagining a scene of future decomposition. As such, the description is rather more metaphorical than the others and, in accordance with Kokobobo's definition, figures as an example of a realism that is more grotesque than abject.

On the basis of the positioning of the other corpses and their coffins, the narrator deduces that the next empty grave belongs to a young man. The details of this body form the centre-piece of the narrator-detective's account of the crime scene. Not surprisingly, it is here that the story's abject realism reaches its apogee. Whereas the descriptions of the first corpses evoke a sense of revulsion primarily because they emphasize the state of decomposition, the picture of this man's corpse creates its effect by refusing to shy away from the violent mutilation to which it has been subjected. The narrator explains:

трупа его в сущности не было, потому что он был с изуверством, не знаю по каким причинам, просто растерзан: голова оторвана от туловища и ее едва только, после долгих поисков, я нашел на краю кладбища в канаве, с куском грязной тряпки, которой заткнут был рот. Глаза проткнуты, а нос и уши отрезаны. (298)

In reality, there wasn't really a body because it had been, I know not for what reason, simply torn to pieces with barbaric cruelty: the head had been ripped off the torso and, only after a long search, did I find it at the edge of the cemetery in a 
ditch with a dirty piece of cloth stuffed into the mouth. The eyes had been gouged and the nose and the ears cut off.

The narrator's acknowledgement of his sense of horror ['prosto uzhas'] at the disfigurement of the face infects readers, even though our access to the body is only indirectly mediated through the text. As further gruesome details of the man's body are provided, our sense of aversion is heightened:

Недалеко от головы лежала правая рука, оторванная у локтевого сустава; третьего пальца не было. Левая рука оказалась при туловище страшно обезображенном: грудь проткнута в нескольких местах, по всей вероятности, колом; из отверстий текла сукровица, живот разрублен с частью левого бедра, ноги от туловища у колен были отделены. Видно было, что это оперативное отделение происходило при помощи топора, который оставил по себе явственные следы зарубок на костях. Самые ноги лежали на груде мусора и были раздроблены по всей вероятности камнем, брошенным на них сверху. (298-9)

Not far away from the head lay the right arm, ripped off at the elbow; it was missing the third finger. The left arm was found close to the horrifically mutilated torso: the chest was punctured in several places, in all probability by a stake; a watery discharge [ichor] seeped out of these holes. The stomach had been cut with an axe along with a part of the left hip; the lower legs had been amputated at the knee. It was evident that this operation had been done with an axe, which had left clear traces of notches on the bones. The lower legs themselves lay on a pile of rubbish and had been crushed by a stone, in all likelihood, dropped onto them from above. 
This description of the violence enacted on the young man's body after death gives a clear idea of the level of detail employed in Timofeev's narrative. The generically unconventional approach that it represents cannot be explained simply by suggesting that the degree of mutilation suffered by this body is greater than that encountered in other works. Many of the crimes featured in late Imperial Russian crime fiction are extremely violent and entail gruesome consequences; they are just not described in such uncompromising detail. ${ }^{24}$ The repeated references here to decapitation, amputation, mutilation, and perforation combined with the descriptions of the liquid oozing from the chest wounds undoubtedly qualify the realism employed as abject. As the cited text reveals, the investigator finds himself dealing with an entity that is simultaneously a body and not a body, whose various parts both suggest and deny meaning. The blurring of the line between human and non-human achieved in Timofeev's earlier descriptions both of mutilation and decomposition is intensified here by the image of the young man's lower legs lying on a pile of rubbish. Echoing the description of the young girl, the realism employed here appeals not just to sight but also to touch, in the textural details of the seeping ichor and the incisions made on the bone by the axe. The passage is abject in its

${ }^{24}$ In P.I. Stepanov's collection Pravye i vinovatye: zapiski sledovatelia sorokovykh godov [The Innocent and the Guilty: Notes of an 1840s Investigator] (1869), the story 'Uzdechka konokrada' ['The Horse-Rustler's Bridle'] features the accidental murder of the eponymous criminal who suffers a large and fatal head wound when villagers try to release him with an ill-directed axe strike from the bridle with which they have bound him to a cart. Meanwhile, in S.A. Panov's 1876 novella, Tri suda, ili ubiistvo vo vremia bala [Three Courts, or Murder During the Ball], the female victim has her throat slit deeply from behind by a razor blade wielded by her supposed best friend. 
presentation not only of an extremely violated body, but of a taboo act: the desecration of a dead body. ${ }^{25}$ The subsequent revelation that the person responsible for this crime is, in fact, the victim's father highlights the sense of this mutilation as a taboo act even more. The narrator's reminder a few lines later of the world's natural order further underscores the transgressive acts of violence inflicted upon this body after death. He notes how the man's clothes were removed before the mutilation occurred and found near a clump of acacia trees elsewhere in the cemetery. The contrast between the tranquility of the trees and the dehumanized body powerfully affects the reader.

Significantly, the heightened realism in this description of the cemetery does not respond to any sort of voyeuristic impulse in the narrator-detective. The various details of the mutilated corpse do not render the account sensational. The protagonist derives no pleasure from the picture of violence with which he is confronted, apart from what might be termed the pleasure of the epistemic challenge it presents. Nor is there any evidence of the 'violence of the gaze' that can sometimes characterize accounts of extreme brutality; the investigator's observation of the bodies in the cemetery does not re-violate them. The repeated interjection, 'po vsei veroiatnosti' ['in all probability'], which indicates the investigator's efforts at deduction, serves to remind readers that his primary aim in recording the minutiae of the scene is, as he has said, to discover the truth'. Although, as his earlier admission of horror has made clear, the detective is not entirely detached from what he sees, his attitude is primarily professional, rather than

25 Edith W. Clowes argues, in relation to Leonid Andreev's works, that 'the abject is marked by the physical body - violated, debilitated or dead, while psychologically the abject can refer to taboo urges and fears in the unconscious of the protagonist' (p.238). 
personal. Not only do his observations of the crime scene allow him to suggest interpretations of how particular injuries might have been inflicted upon the man's body, they also ultimately convince him that it is precisely the extreme degree of mutilation suffered that constitutes the most significant clue in the case. He surmises that, since only this body has been mutilated, the ransacking of the cemetery and the disinterment of the other bodies must have been conducted with the sole aim of finding it. This hypothesis informs the remainder of his investigation as he begins by questioning the parents of the disinterred young man, Andrei Bogitko, about possible motives for the crime.

Although this initial description of the scene in the cemetery represents the most sustained appearance of abject realism in 'A Crime of Superstition', the element of abjection does not disappear entirely from the remainder of the story. Having ascertained that Andrei Bogitko has died about three weeks previously from smallpox, the narrator's early investigative efforts are thwarted by the fact that he appears to have had no enemies to speak of, and that his parents deny all knowledge of what might have motivated this sacrilegious act. However, by investigating the body of the strangled black cat found in Andrei's grave, the narrator comes full circle back to his parents who ultimately confess to having sacrificed it in an effort to ward off visitations from their dead son. Andrei's father, Stepan, promises the investigator and a crowd of gathered villagers that he will reveal everything 'kak pered Bogom' ['as if before God'] (306) if they follow him to his son's grave. As they stand in the cemetery, the narrator describes how Stepan approaches the grave, picks up a little stick and:

\footnotetext{
вытащил оттуда (...) нижнюю холщевую подстилку из-под покойника, потом тем же путем выбросил из изголовья подушку, набитую сеном, уже замаранную и пропитанную мозговою жидкостью. Тронутая с места она
} 
распространила убийственный запах. Зажав нос и рот левою рукою, Богитко, наклонившись с изголовью, продолжал рыться палочкою в сене и наконец выкинул оттуда какой-то грязный вонючий узелок (...) узел[ок], равно как и подушка из гроба, был весь пропитан гноевидною жидкостью, и издавал смрад. (306-7)

using [it], pulled out a piece of linen material from under the corpse; then, using the same method, threw out from the place where the head lay a pillow stuffed with hay that was already smeared and soaked with brain matter. Moved from its position, this pillow dispersed a murderous smell. Having covered his nose and mouth with his left hand, Bogitko, leaning towards the place where the head lay, continued to poke the hay with the stick and eventually extracted some sort of dirty, fetid little knotted parcel (...) the parcel, exactly like the pillow from the coffin, was completely soaked with suppurating liquid, and gave off a stench.

Although this description ostensibly concerns non-human objects, it clearly contributes to the story's pursuit of an abject aesthetic. Crucially, the fact that both the pillowcase and the knotted parcel are soaked in bodily fluids blurs the usual borderline between animate and inanimate matter. This disruption of fundamental distinctions between types of matter creates a sense of abject ambiguity and disturbs the reader's sense of conventional decorum. This passage also echoes back to the earlier abject descriptions by using a similar vocabulary and the repeated use of terms related to putridity, dirt, and smell. Likewise, the depiction is strongly textural and olfactory as well as visual: an elevated sense of realism is achieved by the use of two verbal adjectives ['smeared' and 'soaked'] to describe the contamination of the pillow, and the earlier references to 'vozdukh' ['air'] are replaced here by the more forceful 'smrad' ['stench']. Beyond the description's 
materiality, the reader's sense of disgust is complicated by a feeling of empathy for Andrei's father who is having to interact in this way with the rotting body of his son. Significantly, no words are spoken by any of the parties as these actions are performed, but their abject nature gives eloquent voice to the experience of horror.

Abject realism makes one final, brief appearance in the closing stages of 'A Crime of Superstition' when the narrator-investigator has learned definitively that Stepan Bogitko and his neighbour, Pankrat, are responsible for the disinterment of the graves and the mutilation of Andrei's body. The narrator indirectly reports Stepan's testimony regarding what happened on the night in question: both men drank considerable amounts of alcohol to try to calm their acute sense of fear and disgust about what they were about to do and their inebriation explains why it took them several attempts to locate the correct grave. Upon finding it, they took Andrei out of the coffin, undressed him and then, in order to prevent the body from screaming (as they have been warned might happen), they: 'zatknuli emu rot triapkoi, potom otovrali golovu, protknuli glaza, otrezali nos i ushi, zatem prinialis' i za tulovishche' ['stuffed his mouth with a rag, then ripped off his head, gouged out his eyes, cut off his nose and ears, and then set about the torso'] (320). The sense of aversion aroused by these details is not as pronounced as in earlier instances, a lesser effect that can be explained by two factors: first, the account repeats details already known by the reader, thereby decreasing the sense of shock; second, the description itself is shorter and does not dwell on the details to the same extent. Significantly, the narrator explicitly acknowledges the repetitions in the description when he declares: 'ne budu povtoriat' togo iz etoi vozmutitel'noi kartiny, chto bylo uzhe govoreno vyshe, skazhu tol'ko, chto trup obezobrazhen byl do nel'zia' ['I will not repeat what has already been said above about this appalling scene; I will only say that the body was disfigured beyond 
all recognition'] (320). This statement conveys the narrator's disinclination to record detailed scenes of violence unnecessarily; it argues that his motivation is neither the sensationalization of the crime nor the empty titillation either of himself or his readers. Moreover, it implies that the narrator not only acknowledges the effect that his abjectly realistic descriptions have produced, but also that this approach has served its purpose and can now cease. Indeed, in the story's few remaining pages, the narrator does not relate any more abject details and concludes his account by noting simply that both Stepan and Pankrat are jailed for their crimes.

Having established the nature of the abject realism in 'A Crime of Superstition', the question remains: what are the effects - beyond the provocation of a sense of shock and aversion - of the story's inclusion of such detailed scenes of violence, mutilation and decomposition? I would contend that they are manifold, but many reach, albeit in relatively atypical fashion, to the heart of the generic conventions of Russian crime fiction in the late Imperial era. The decision to present a picture of the consequences of Stepan and Pankrat's crime in such unflinching detail constitutes a challenge to the prevailing cultural convention of masking the realities of such violence. The approach here obliquely recalls Петербургские трущобы [Petersburg Slums] (1864-67) of V.V. Krestovskii, whose physiological sketches of members of the lower classes in the city were inspired by Eugène Sue's Les Mystères de Paris (1842-43). In the foreword, Krestovskii reminds readers of their obligation to confront unpleasant accounts of life's realities, using words that might be equally well applied to 'A Crime of Superstition': 'Look! It's no use turning away with a shudder and closing your eyes! This is our own, this is the product of our 
society!'. ${ }^{26}$ Similarly, Timofeev's story is an account of the realities of both life and crime, but the abject aesthetic, more stridently than conventional realist works, reminds the reader of her responsibility to acknowledge the existence of these social truths. The more extreme emotional response provoked by the refusal to look away from the aftermath of crime in 'A Crime of Superstition' is also significant. Because of their tendency to unmask culprits at a relatively early stage following a reasonably straightforward investigation, few early Russian crime stories present the type of cerebral challenge typical of the classic 'whodunit'. Timofeev's story exaggerates this model, however, by having the reader (and the detective) experience a more visceral reaction to the depiction of crime, one centred far more in the stomach (and nose) than in the brain. 'A Crime of Superstition' demands that the reader not just 'think' about crime, but 'feel' its effects, although it is by no means explicit about what, if anything, she should do in response to this abject experience.

Although the story's use of abject realism inspires the reader's revulsion, it simultaneously provokes a heightened degree of empathy for the characters in the fictional world, especially the narrator-detective. The foreword to the collection in which this story appears blurs the line between fact and fiction, thereby encouraging the belief that, while the reader experiences disgust in response to the description of these scenes, the narrator-detective confronts them directly and unmediatedly, and so his revulsion must be stronger. However, he never expresses self-pity, and his conduct throughout the

26 V.V. Krestovskii, Peterburgskie trushchoby (Moscow: Pravda, 1990). The translation is taken from Julie A. Buckler, Mapping St Petersburg: Imperial Text and Cityscape (Princeton, NJ: Princeton University Press, 2005), p.174. 
investigation is simultaneously professional and humane. In fact, the abject proves to be a particularly effective means of enacting one of the recurrent features of early Russian crime fiction: the depiction of the investigator as an authoritative, educated outsider who enters a relatively closed, ignorant and fearful rural world. The earliest instances of this abject realism (that is, the repeated references to the stench from the cemetery) permit the narrator to demonstrate his standing as a man of action and reason at the very outset. He displays his greater knowledge when he instructs the villagers to cut down nearby pine trees and to burn them as a means of masking the smell of decomposition that so perturbs them all. The discovery that what Stepan Bogitko and Pankrat have done to Andrei's body (both men disinterred and mutilated the body and Pankrat placed a padlock wrapped in knotted linen in the coffin) is the result of superstitious belief constructs a stark contrast between the rational, skeptical investigator and the credulous and fearful villagers. The decision to portray in such abject terms the enactment of the outlandish and self-serving advice given by a wandering beggar woman and a local fortune teller powerfully underscores the violence and inhumanity that results from placing trust in superstition and mysticism. And, while it is in the actions of Stepan and Pankrat that such beliefs are shown to be most pernicious, the narrator's various encounters make clear that they are shared by all of the Gerdovaia villagers. His amazement that the village elder still believes in the 'nelep[ye] bredn[i]' ['ridiculous nonsense'] (293) of the walking dead and his characterization of the beggar woman as 'obmanshchitsa starukha' ['the old woman deceiver'] (314) cast the investigator, in contrast, as the representative of modern modes of thinking, based on reason and logic.

The abject descriptions of the violence committed against Andrei also underscore the pernicious effects of drunkenness in this rural community. Although the idea to disinter 
his body is the product of superstition, this plan is only enacted after Stepan and Pankrat have imbibed so much vodka that their sense not just of fear, but also of morality, is entirely deadened. The narrator's opposition to such drunken behaviour is largely oblique: by the sober, professional conduct of his investigation, he functions as a positive counter-example. However, he makes his position more explicit towards the close of the story when he offers the following warning to the villagers:

Не верьте вы в эти глупости (...) тогда у вас и дел таких скверных никогда не будет. Не то колдуньи и водка многим из вас еще навредят, если вы будете первым верить, а с последней брататься. (323)

Don't believe in this nonsense (...) that way you won't experience these dreadful events. Many of you will continue to be harmed by these witches and this vodka if you carry on believing the former and mixing with the latter.

Russian literature had long featured superstitious belief by the time that Timofeev's story was published in the early 1870s. Thanks to the use of abject realism, however, its treatment here is quite distinct from its more benign depictions in the folk and fantastic tales popular in the Romantic era. Gone are the humorous and wry depictions of folk belief in works such as Antonii Pogorel'skii's 'Lafertovskaia makovnitsa' ['The PoppySeed Cake Seller of the Lafertov District'] (1825) or Aleksandr Pushkin's 'Grobovshchik' ['The Undertaker] (1830). ${ }^{27}$ In their place stand extended passages featuring a stridently

27 In Pogorel'skii's story, the eponymous heroine promises her niece and sister-in-law part of her fortune but only if they agree that the former should marry a man of her choice, who turns out to be the fortune-telling aunt's black cat in human form. Meanwhile, in Pushkin's story, an inadvertent toast to an undertaker's clients leads to the apparent visit 
realistic depiction of horrific violence perpetrated against a dead body that acts as a damning indictment of such beliefs. Behind the criticism aimed at individual characters by this use of the abject stands a more generalized, albeit implicit, denunciation of the broader social organization that permits such communities to fall victim to the violence informed by ignorance. For the narrator-investigator, the mutilation of Andrei Bogitko's body is much more than an act of sacrilege: it is the sort of taboo act that proceeds from a form of social organization that converts fear and ignorance into a father's ability to inflict almost unimaginable, utterly transgressive violence upon his son's body. And while the investigator's professional role allows him to act as a bulwark against such harmful modes of thinking and behaviour, the abject exposes the actual limitations of his effect. More stridently than other works of crime fiction, therefore, 'A Crime of Superstition' points an accusatory finger not at individuals but at social constructs, particularly social stratification, an accusation rendered all the more powerful by its use of this extreme realist mode.

\section{‘On One’s Conscience’ (1879)}

Timofeev's 1879 story, 'On One's Conscience: A Psychological Sketch', uses the abject primarily to target the judicial and penal systems. The narrative throws the inhumane and damaging effects of these systems into stark relief by means of an implied comparison with the empathetic attitude of the narrator-investigator. However, in a manner that chimes with Clowes' claim regarding the later work of Andreev, the presence of an exaggerated realist mode in Timofeev's narrative also 'reveals an existential horror

by various of these corpses and skeletons, but in a scene that is characterized primarily by a sense of the humorous grotesque. 
at the human condition'. ${ }^{28}$ To an even greater degree than 'A Crime of Superstition', this story is principally preoccupied with the question of 'whydunit'; however, the exploitation of the abject ensures that this generic characteristic, which is a commonplace in early Russian crime fiction, receives original and provocative treatment. At the outset, the narrator-investigator is introduced to a man, Aver'ian Pavlov, who has been arrested for attempting to murder his wife by cutting her throat. Since Aver'ian's guilt is never at issue, the detective focuses instead on the question of motive, or what he calls the 'nravstvennye sostoianiia' ['moral conditions'] surrounding the crime. ${ }^{29}$ In this regard, he differs sharply from his police counterpart, who is unwilling to countenance the idea that extenuating circumstances might exist for any crime. During this historical era, such a contrast between a police officer and a newly-instituted judicial investigator was a common feature of Russian crime fiction. However, 'On One's Conscience' distinguishes itself from other such works in the ambiguity that abject realism creates around the question of 'whydunit': the use of the abject appears to extend the possibility of some meaning being expressed while simultaneously thwarting the investigator's efforts at interpretation.

Significantly, although abject realism unmistakably features in the descriptions of Aver'ian's post-crime actions, specifically his attempts at self-harm, it does not feature in the account of his attempt on his wife's life. The narrator provides only brief details about

${ }^{28}$ Clowes, 'The mute body', p.237.

${ }^{29}$ N.P. Timofeev, 'Na sovesti: psikhologicheskii ocherk', in the collection Iz ugolovnoi khroniki (Moscow: Lavrov, 1879), p.7. Henceforth, references to this story will appear in parenthesis in the main body of the article. 
his attempted murder: five days after his return from a work trip to Moscow, Aver'ian sends his wife out into the field, ostensibly to fetch a horse, follows her and, with a previously prepared knife, inflicts a deep wound to her neck. Such a summary report conforms entirely with conventional practice in early Russian crime fiction. The difference in the level of detail does not evince a lack of concern about violence perpetrated against a female victim, however. Rather, it emphasizes the investigator's belief that Aver'ian's subsequent acts of self-mutilation potentially have more to teach him about the suspect's state of mind and motivation than does the original crime. The status of these acts as an alternate, non-verbal means of communication is never acknowledged explicitly in the story; however, their occurrence coincides with either false or absent speech acts from Aver'ian. So, for example, his first act of self-harm (the swallowing of phosphorous match heads in an attempt to poison himself) comes after the investigator has visited the jail and heard Aver'ian admit his guilt but invent a clearly false motive. A bridging incident between this first attempt and the later, even more serious ones, occurs when other prisoners, angered by Aver'ian's refusal to meet with his wife, attack him. The narrator reports that: 'sredi draki emu byla nanesena dovol'no sil'naia rana takim zhe kochedykom v levuiu nogu, kotoraia proshla dovol'no gluboko v miagkie chasti tela, i obnazhila kost" ['during the fight he sustained a relatively serious wound to his left leg, inflicted by the weaving knife; the wound penetrated quite deeply to the soft tissue and revealed the bone'] (96). Whilst brief, this description nevertheless contains more specific detail than the account of Aver'ian's attempted murder of his wife. Moreover, the reference to how the inorganic weapon penetrates his animate flesh is relatively gory. For a man who so obstinately refuses to reveal the inner motivation of his crime, the violent exposure of his inner matter comes to seem somehow symbolic. 
In fact, two further factors reinforce the sense that Aver'ian's detention in the jail functions as the external manifestation of his apparent post-crime psychological imprisonment: when he repeatedly exacerbates his leg wound, he is restrained in a straitjacket; and when he refuses to behave upon his release from the hospital ward, he is placed in solitary confinement, not once but twice. While these additional curbs on his freedom speak to a certain inhumanity in the prison system, it should also be acknowledged that Aver'ian appears to seek out this punishment by means of his rebellious behavior. The narrator notes that through these actions 'nachali vyrazhat'sia simptomy ego dushevno boleznennogo nastroeniia' ['the symptoms of his spiritually-ill mood began to express themselves'] (89). The abject's significant role in that expression first becomes evident when the prison guards report that, while in solitary confinement, Aver'ian has conducted, what they call, 'kak[aia]-t[a] operatsi[ia]' ['some sort of operation'] (99) on his own leg. The indefinite pronoun here recalls the use of the same part of speech in 'A Crime of Superstition', and the guards' recourse to a term expressing their incomprehension becomes evident when Aver'ian's actions are described:

Аверьян Павлов, в углу земляного пола карцера, нашел какой-то обломок стекла, которым прежде всего разбередил себе до крови и вскрыл на ноге свою рану, затем при помощи того же стекла, наскоблил с каменной стены карцера известки, и всыпал ее себе в рану, и мало того, натаскал из своей подушки несколько конских волос, которыми она была набита, тем стеклом нарезал их на маленькие кусочки, и засунул в ту же рану, которую сверху присыпал песком. Само собою разумеется, что в течение какого-нибудь часа времени, снадобья эти вздули ногу Аверьяна до невообразимых размеров, из нее показалась кровь, обильный гной и его снова положили в больницу. (99) 
In the corner of his cell, on the dirt floor, Aver'ian Pavlov found some shard of glass or other with which, first of all, he drew blood and opened up the wound on his leg. Then, using this same piece of glass, he scraped bits of limestone off the walls of his cell and sprinkled it into the wound; furthermore, he also pulled out some of the horse's hair with which his pillow was stuffed, cut it into little bits using the piece of glass, stuffed this into the wound and then added dust over the top. One can figure for oneself that in the space of an hour or so, these substances made Aver'ian's leg swell up to unimaginable proportions; blood and abundant amounts of pus came out of it and he was sent back to the hospital ward.

The juxtaposition of animate and inanimate constructed here in multiple references to Aver'ian's physiognomy (his leg, its wound, the blood) and to the substances he finds in his environment to injure himself clearly evokes a strong sense of the abject. Most especially, the status of many of these substances as forms of waste make them particularly inappropriate for insertion into a wound and therefore arouse a sense of aversion. They underscore the lack of hygiene that logically typifies Aver'ian's physical location in the prison cell but also suggest that his surroundings are having a detrimental effect upon his mental state: a person in his right mind would not harm himself in this way. The references to the swelling of his leg and the pus that issues from it emphasize the physical disfigurement consequent on the 'moral conditions' that Aver'ian is experiencing. The fact that both the swelling and the pus are qualified as excessive strengthens the sense of abject suffering being expressed and reported in gruesome terms. Crucially, Aver'ian offers no explanation of his act, and while not entirely mute like the bodies that Clowes identifies in Andreev's work, he is described as being largely unresponsive to the prison staff and increasingly incoherent in his interactions with the narrator-detective. He continues to express himself primarily through physical actions, 
even if these are not always abject in nature: he rips off his own clothes, breaks windows, smashes crockery, and gets into fights with other prisoners as well as guards. While the prison staff continue to believe that Aver'ian is a healthy troublemaker, the narratorinvestigator does not concur. Rather, he reads all of these actions as the external expression of an inner turmoil, although he remains uncertain about whether this turmoil prompted the crime, or flows from it, or perhaps both.

Aver'ian's persistent acts of self-harm further convince the narrator that the prisoner is 'spiritually unwell'. He relates how Aver'ian uses a knife from the prison kitchen to cut off half of his little finger and then borrows a needle and thread the following day and pierces his tongue with it whilst standing at the dark end of a corridor. Although not as distinctly abject as the earlier descriptions, these additional episodes of self-harm promote the idea that Aver'ian is dealing with some form of deep-seated trauma that has led him to become alienated from his own body. These acts of self-mutilation begin to reveal, and perhaps also create, an anxiety about the distinction between subject and object that makes Aver'ian a figure of the abject. ${ }^{30}$ He treats his body less as an integral part of his self as a subject, and far more as an object little different from the various inanimate materials with which he harms himself. During a subsequent conversation with the narrator-investigator, Aver'ian partially reveals the reason for his self-harming: in hesitant and faltering speech, he admits that he hurts himself so as to think less about

30 This is a formulation borrowed from Laura Wilson's Spectatorship, Embodiment and Physicality in the Contemporary Mutilation Film (Basingstoke: Palgrave Macmillan, 2015), p.78. Wilson's reference is to the character of Esther in Marina de Van's 2002 film Dans Ma Peau, but it applies equally appropriately to Aver'ian in Timofeev's story. 
what he has done to his wife 'potomu ob nei vsia dusha bolela... (...) s golovy ona u menia ne shla... podumaiu, chto ia ei sdelal... zhalko...' ['because my whole soul hurts about her... (...) I can't get her out of my head... I think about what I did to her... I'm sorry for her...'] (110). The narrator admits that this confession helps him to understand and to normalize Aver'ian's actions: 'Aver'ian tomilsia mysl'iu o tom, chto on vinovat pered svoei zhenoi, ego mochila sovest' i on, kak vidno, tiazhelo iznyval soznaniem togo, chto chut' bylo ne lishil ee zhizni' ['Aver'ian was overcome by the thought that he was guilty with regards to his wife; he was tormented by his conscience and, evidently, he was exercized by the knowledge that he had very nearly killed her'] (111). The narrator's belief that he understands the extent of Aver'ian's suffering prompts him to advise a change in the authorities' approach to the prisoner. He recommends that Aver'ian be released back into the care of his family until a hearing can be convened, as he considers it likely that Aver'ian will then be permanently released from detention because of his mental / spiritual state. However, one final act of self-harm violently disproves the narrator's confidence both in the justice of this solution and in his comprehension of Aver'ian's situation.

Three weeks later, Aver'ian's wife visits the investigator's office to inform him that her husband has burned himself to death. The investigator admits his shock at Aver'ian's chosen method of suicide which, he reveals, is the first and only experience of selfimmolation he has encountered during his career. The narrator-investigator sets out that very day to the place where Aver'ian's body has been found. The relatively extensive and detailed description of what he observes is striking for its use of abject realism. As in 'A Crime of Superstition', a sense of incongruity arises from the contrast drawn between the unnaturalness of Aver'ian's act and the natural scene in which he has committed it. The 
fire laid in a small clearing in a forest is composed of a variety of dried tree stumps, twigs and other pieces of wood, and is fairly large at about seven feet in diameter. However, it is the details of Aver'ian's body that evoke the strongest reaction:

Поперек всего костра, лицом к низу, в рубахе и портах, которые сохранились только кое-где в обгорелых небольших местах, лежал труп Аверьяна Павлова, обгорелый до того, что полость груди и живота прогорели насквозь и внутри трупа видны были обуглившиеся внутренности. Оконечности ног уцелели от огня: спина была вся багрового цвета в пузырях, а по бокам, где пламя действовало более косвенно, тело приняло вид - страшно сказать - копченого мяса. Лица покойного нельзя было узнать; вернее сказать, его уже совсем не было, виднелись только обгоревшие и обуглившиеся части костей. Руки лежали под трупом крестообразно, а между ними в одном месте, сохранился небольшой обгорелый остаток веревки, свидетельствовавший, что Аверьян Павлов, в своем безумном решении броситься в пылающий костер, предусмотрительно связать себе обе руки, чтобы отнять у себя всякую возможность подняться из костра. (116)

The body of Aver'ian Pavlov lay right across the fire, face down, wearing a shirt and trousers that were completely burned and of which only pieces remained here and there. The body was so badly burned that the chest cavity and stomach were burned through and the decomposed innards were visible inside the body. The fire had burned off the lower part of his legs; his spine had completely turned a reddish-purple colour and was covered in blisters; 
and down each side, where the flames had not been quite as fierce, the body had taken on the appearance - it is horrifying to say - of cooked meat. It was impossible to recognize the face of the dead man; it would be more accurate to say that it had completely disappeared: only burned and decomposed bits of bone were visible. He had his arms crossed beneath his body, and between them in one place remained a small burned bit of a knot that bore witness to the fact that Aver'ian Pavlov, in his deranged decision to throw himself onto a blazing fire, had had the foresight to tie both his hands together so as to deprive himself of the possibility of getting up out of the fire.

There are obvious points of similarity between the abjectly realistic depiction of Aver'ian's suicide and the mutilation of Andrei Bogitko's body in 'A Crime of Superstition'. Both corpses have been dehumanized by the violence enacted upon them: the narratorinvestigator recognizes them as human figures, but ones that disrupt expectations about how they ought to appear. The fact that there is little distinction between the outside and the inside of the bodies disrupts conventional boundaries and provokes a strong sense of aversion. In the case of Aver'ian, the fact that the flames have turned the spine a reddishpurple colour, rather than the more natural cream or white we expect, is also striking. However, as the narrator acknowledges when he says 'strashno skazat" ['it is horrifying to say'], the most shocking aspect of the fire is that it has rendered Aver'ian's body comparable to a food stuff: cooked meat. Such a description breaks a fundamental taboo against anthropophagy in most human societies. This is a human body entirely deprived of any spirituality and rendered into matter, but matter that strongly evokes disgust when compared to food. 
Because the state of Aver'ian's body is the result of self-inflicted violence, the extreme realism in this passage creates a stronger sense of the psychological abject than that in Timofeev's earlier story. Such a claim does not deny the presence of any psychological impulse in the acts of violence committed by Stepan and Pankrat in 'A Crime of Superstition', but it does suggest that Aver'ian's suicide speaks to a more acute degree of mental trauma. The comparison of Aver'ian's body to cooked meat represents the apogee of the confusion between his status as subject or object that is a feature of all his acts of self-harm. Although a human body is still just about discernible in the ashes of the fire, it is one denuded of a sense of self or subjectivity. Indeed, at this point in 'On One's Conscience', it becomes appropriate to talk about what Kristeva defines as 'the abjection of self'. She explains:

If it be true that the abject simultaneously beseeches and pulverizes the subject, one can understand that it is experienced at the peak of its strength when that subject, weary of fruitless attempts to identify with something on the outside, finds the impossible within; when it finds that the impossible constitutes its very being, that it is none other than the abject. ${ }^{31}$

All of Aver'ian's acts of self-harm up until this point in the story have involved him introducing foreign objects into his body: matches, glass, horse hair, dust, a needle, etc. Although this form of self-mutilation has begun to blur the line between subject and object, the decision to commit suicide by inserting his body into an inanimate object (the fire) creates an image of his body as more fully object, than subject. In Kristeva's terms, Aver'ian's status here as neither fully subject nor object places him firmly in the realm of

${ }^{31}$ Kristeva, Powers of Horror, p.5. 
the abject. In choosing to build a fire and throw himself onto it, while having the foresight to bind his own hands so he is unable to change his mind and save himself, Aver'ian demonstrates his complete loss of self. Ultimately finding his previous acts of self-harm to have been 'fruitless', he commits an act that strikes the reader as psychologically 'impossible'.

It goes without saying that the use of abject realism in 'On One's Conscience' lends a greater degree of truth and authenticity to the depiction of the emotional and psychological anguish that Aver'ian suffers as a result of his crime. Although Timofeev's story is very far from being the only example in Russian crime fiction of a work in which the criminal regrets his crime and experiences remorse, I cannot think of another that makes the reader so starkly aware of the implications of that remorse. More persuasively here than in any other examples of the genre, the reader is asked to reassess her attitude to the criminal: Aver'ian is not simply a 'bad apple' for whom the reader should have no sympathy or empathy; rather he is a man so traumatized by the memory of his crime that he ultimately chooses death. Although the motive(s) behind Aver'ian's original crime are never clarified, there can be no doubt, in the face of the story's various abject tableaux, of the turmoil into which his memory of it casts him. It is admittedly problematic that the reader ends the story with a more elevated sense of empathy for Aver'ian than she has for his wife, who is no less a victim. However, the abject emphasizes the reality and depth of Aver'ian's suffering and ensures that the social criticism typical of Russian crime fiction during this period is all the more strident. What the narrator discovers as part of his investigation into the 'whydunit' serves to accuse far broader forces than the individual Aver'ian. He learns that Aver'ian is not a peasant by birth but the son of a rich landowner who gave him away following his mother's death; Aver'ian struggles to adapt to his new 
way of life and is always seen as different by the members of his new community. Given the suggestion that Aver'ian's sense of social discomfort and alienation acts as some form of trigger for his attack on his wife, the use of the abject therefore functions as a persuasive critique of the rigid social stratification that continued to exist in Russia even after the emancipation of the serfs. However, abject realism in 'On One's Conscience' does not only accuse the system of social class in Aver'ian's case; the unflinching portrayal of the harm that Aver'ian inflicts upon himself illustrates the damage that can be done by means of an undiscerning and unsympathetic application of the justice system. While it might be the case that, having attacked his wife, Aver'ian was unlikely ever to recover, his treatment in the prison and the reluctance of those serving there to treat him with greater compassion arguably exacerbates his situation. Their attitude towards Aver'ian is identical to that of the police bailiff who, at the opening of the story, rejects the idea that there is any value in considering the inner motivations for a crime. The detention of Aver'ian after his crime means the letter of the law is applied (its external form, if you like) but no acknowledgement of the internal consequences of fulfilling this protocol is provided. The use of the abject thus underscores the failure of the reformed judicial system to respond to Aver'ian's needs. It not only cautions against a belief that the recent reforms are a panacea against all the previous ills, but makes an implicit plea for something even more humane.

In an even more original move, although the investigator-narrator is depicted as a more empathetic figure than the judicial system, the use of abject realism creates a nuanced impression of this protagonist. On the one hand, as in 'A Crime of Superstition', the presence of the abject serves to paint the detective in a positive light: he is shown to be emotionally affected by the horrific scenes that he has to confront, but always 
professionally engaged in the pursuit of the truth behind the case. As Aver'ian demonstrates his persistent alienation from his own self through his acts of self-harm and eventual suicide, the judicial investigator is portrayed as desperately, although ultimately unsuccessfully, attempting to uncover Aver'ian's true identity. The investigator's attitude clearly implies that a better understanding of that identity might lead to a connection with Aver'ian as a subject, which, in turn, might ensure his survival. In spite of his best efforts, including his humane approach to Aver'ian and his family and a willingness to depart from legal statute to allow his release, the investigator does not succeed, however. Indeed, not only does he fail to solve the initial mystery of Aver'ian's attempt to kill his wife, he is ultimately faced with another irresolvable question, rendered all the more acute because of its abject nature: why did Aver'ian choose to kill himself in such a gruesome fashion? The interrogatives and the ellipses employed repeatedly in the story's closing three paragraphs give eloquent expression to the challenge presented by Aver'ian's case and the investigator's professional and personal, intellectual and emotional approach to it. He ponders whether the gruesome nature of Aver'ian's death was intended precisely as the most appropriate form of self-punishment for his earlier crime. However, he arrives at no definitive answers. The abject is, contradictorily, not only the most effective expression of Aver'ian's sufferings, it ultimately tells the investigator very little. Consequently, while the story allows Timofeev to present the judicial investigator as a new breed of literary hero, willing to cast a critical eye over the realities of life in post-reform Russian, it also makes clear that this figure is no all-seeing, all-comprehending superman.

\section{Conclusion}


A discussion of the practice of abject realism in early Russian crime fiction demonstrates the considerable variety that existed within the genre from its very earliest stages. While some works chose to adopt a more aesthetically sanitized approach to depicting the acts of violence that so frequently lie at the heart of the genre, others preferred to pursue a more extreme poetics, possibly in search of a greater truth-value. In the two stories discussed here, the abject clearly offers a means of more stridently criticizing various aspects of Russia's social organization during the 1860s-1870s than is encountered in other works of crime fiction. The abject thus gives the lie to the often-expressed view of crime fiction as an essentially reactionary genre that serves to reinforce the cultural and political status quo. In viscerally depicting violence, works of crime fiction that employ the abject also implicitly argue for a form of realism that acknowledges the value of an emotional and not just an intellectual response to literature. There can be no doubt that the reader is supposed to react with revulsion when confronted with these minutely described scenes of (self-)mutilation, although it is not entirely clear what longer-term moral response is advocated. However, as the consideration of these two stories by Timofeev has proven, it is essential to recognize that even those works of crime fiction that deploy this more radical realist vision do not do so in a uniform fashion or to identical ends. Indeed, it would be ironic if a concept - the abject - that is 'above all ambiguity'32 came to advance a monologic interpretation. While in 'A Crime of Superstition' the abject constructs a view of the judicial investigator's qualities as overwhelmingly positive that is in line with generic conventions, in 'On One's Conscience', the implied attitude to this new literary protagonist is more ambivalent. At the same time as the abject underscores, in gruesome terms, the finality of Aver'ian's death, it subtly creates a sense of nuance and

32 Kristeva, Powers of Horror, p.9. 
open-endedness to the investigator's search for truth and meaning in both his subject's crime and his suicide. What this discussion has clearly shown is the valuable potential that can be released by a use of the abject: in the works of Timofeev, it enriches both traditional modes of realism as well as conventional models of crime fiction.

University of St Andrews

Claire Whitehead

Department of Russian

University of St Andrews

Buchanan Building

Union Street

Fife

KY16 9PH

cew12@st-andrews.ac.uk 